\title{
Anti-Peptic Ulcer Potential of a Polyherbal Mixture in Indomethacin-Induced Rat Model
}

\author{
Ighodaro $\mathrm{OM}^{1 *}$ and Adejuwon $\mathrm{AO}^{2}$ \\ ${ }^{1}$ Department of Biochemistry, Lead City University, Nigeria \\ ${ }^{2}$ Department of Microbiology, Lead City University, Nigeria
}

Submission: February 12, 2018; Published: February 23, 2018

*Corresponding author: Ighodaro OM, Department of Biochemistry, Lead City University, Ibadan, Nigeria, Email: macigho@gmail.com

Abstract

Aim: In view of folklore usage and therapeutic claims, the anti-ulcerative potential of a formulated polyherbal mixture (PM) containing Adenopus breviflorus, Pterocarpus osun and potassium ash was assessed in indomethacin-induced rat model, using Cimetidine as a reference drug.

Material and Methods: Twenty-four male adult Wistar rats were randomized into four study groups ( $\mathrm{n}=6)$ as follows: (1) normal control, (2) indomethacin control (3) Indomethacin and Cimetidine treated (4) Indomethacin and PM treated. Indomethacin was administered via intraperitoneal (i.p) route at a dosage of $40 \mathrm{mg} / \mathrm{kg}$ of body weight (BW), preceded by oral (p.o) treatments of groups 3 and 4 animals with Cimetidine and PM respectively, twice daily at $8 \mathrm{~h}$ interval for 7 days.

Results: PM-pre-treated animals showed significant improvement against indomethacin-induced ulceration vis-à-vis the evaluated indices (gastric volume, free acidity, total acidity and pepsin activity). This is evident by the photomicrographs of the stomach linings of the PM-treated animals when compared to those of indomethacin-control group. However, the anti-ulcerative effect of PM was significantly lower than that expressed by Cimetidine, a known anti-ulcerative drug.

Conclusions: The results obtained in this study apparently lend credence to the folklore anti-ulcerative claim on PM. Nonetheless, it is necessary to carry out both acute and repeated dose toxicity studies on the 'drug mixture' to ascertain its herbal safety before any recommendations regarding its use as an anti-ulcerative agent is made.

Keywords: Polyherbal mixture; Adenopus breviflorus; Pterocarpus osun; Potassium ash; Peptic ulcer; Indomethacin

\section{Introduction}

The therapeutic efficacy of polyherbal mixtures of different combinations against various ailments, ranging from diabetes, hypertension to Hyperlipidemia is well documented by several animal studies [1-3]. The low cost, easy availability and assumed fewer side effects associated with herbal formulations compared to synthetic drugs have greatly increased their global acceptance and medicinal relevance, even among medical practitioners. In the same vein preferential use of natural remedies to treat ulcerative damages is increasingly becoming popular [4-6]. Peptic ulcer which includes gastric ulcer and duodenal ulcer is a distinct breach in the mucosal lining of the stomach (gastric ulcer) or the upper part of the small intestine (duodenal ulcer). The former is more prevalent and remains a health burden on almost $10 \%$ of the world populace $[7,8]$. The possibility of individuals suffering from both ulcers also exists, and this condition is known as gastro-duodenal ulcer [9]. Physiological imbalance between aggressive factors such as pepsin and hydrochloric acid and protective factors like bicarbonate and mucus in the stomach is principally responsible for ulceration of the stomach and duodenal linings [10.11]. This imbalance has been primarily attributed to chronic inflammatory actions of Helicobacter pylori that colonize the antral mucosa [12-14].

H. pylori causes chronic active gastric (type B gastritis) resulting in a defect in the regulation of gastrin production (decreased or increased production). The bacterium damages the mucus that protects the stomach and small intestine, consequently exposing the linings of these organs to corrosive acidic effects $[14,15]$. Unfortunately, the immune system is unable to clear $H$. pylori infection despite the appearance of antibodies [16]. In summary, peptic ulcer occurs as a result of either excess acid volume or decreased mucus secretion in the stomach and small intestine. This explains why the use of histamine receptor blockers (H2 blockers) such as Cimetidine and ranitidine or proton pump inhibitors (PPIs) like lansoprazole and omeprazole which lower acid volume to protect the stomach lining, as well as antibiotics and mucosal protective agents capable of fighting bacteria to enhance mucus secretion, are often recommended to ulcer patients. Bad dietary habits and excessive use of non- 
steroidal anti-inflammatory drugs (NSAIDs) such as aspirin and ibuprofen are other factors considered as proponents of gastric ulcer [17]. In Africa and most part of the world, herbs concocted locally have been claimed to be effective in preventing or protecting against stomach ulceration [18-21]. In south west part of Nigeria, particularly among the Yoruba indigenes, a polyherbal formulation (PM) composed of Adenopus breviflorus, Pterocarpus osun and potassium ash has been widely used and acclaimed to be a viable anti-ulcerative agent.

Although a couple of herbal remedies have been noted to be effective against disease conditions for which synthetic drugs have been found wanting, however, some others upon scientific examination do not elicit the therapeutic characteristics locally ascribed to them. More so, in some cases, long term usage of some of these formulations impacts negatively on the vital organs of the body owing to herbal toxicity. The present study therefore sought to investigate the anti-ulcerative potential of PM in indomethacin-induced rat model, with Cimetidine as a benchmark. The outcome of this study will certainly provide very important information about the potential of PM as a viable anti-ulcerative agent.

\section{Materials and Methods}

\section{Collection of components and preparation of polyherbal mixture}

Adenopus breviflorus (Tagiri), Pterocarpus osun and potassium ash were the constituents of the polyherbal mixture used in this study. Adenopus breviflorus and Pterocarpus were bought locally at the main market, Ile-Ife, Nigeria, and were identified at Obafemi Awolowo University Hebarium (OAUH), Ile-Ife, whereas potassium ash was obtained from Chemistry Department of the institution (OAU) Ile-Ife. Adenopus breviflorus weighing twentyfive grams (25g) was cut into equal halves, the pulp and seeds were removed into 1 litre of distilled water in small size plastic bucket, to which $1 \mathrm{mg}$ each of Pterocarpus osun and potassium ash was also added. The mixture was properly stirred and left to stand overnight $(24 \mathrm{~h})$. After which the preparation was sieved repeatedly with muslin cloth of different pore sizes, and the filtrate was properly stored at $4{ }^{\circ} \mathrm{C}$ until required.

\section{Collection and management of animals}

Twenty-four male rats of the Wistar strain, with mean weight of $158 \pm 12 \mathrm{~g}$ were used for the study. The rats were purchased from the Animal Breeding Unit, Department of Anatomy, University of Ibadan. All procedures for maintenance and sacrifice (care and use) of animals were carried out according to the criteria outlined by the National Academy of Science published by the National Institute of Health [22] and approved by Lead City University Ethical Committee on Animal Research (LCUECAR). The animals were handled humanely, kept in plastic suspended cages, placed in a well-ventilated and hygienic rat house under suitable conditions of room temperature $(27 \pm 2$ ${ }^{\circ} \mathrm{C}$ ) and humidity. They were provided rat pellets with water ad libitum and subjected to a natural photoperiod of $12 \mathrm{~h}$ light and $12 \mathrm{~h}$ dark cycle. The animals were allowed 2 weeks of acclimatization before the commencement of the study.

\section{Indomethacin induced gastric ulcer model}

The animals were randomly assigned to four groups as shown in Table 1. Groups I and II were administered saline, while Groups III and IV were pre-treated with Cimetidine (100mg/ $\mathrm{kg} \mathrm{BW}), \mathrm{PM}(7.1 \mathrm{~mL} / \mathrm{kg} \mathrm{BW})$ for 7 days. On the 8th day, gastric ulcer was induced by the method described by Bhattacharya et al. [23] with slight modification. Indomethacin $(40 \mathrm{mg} / \mathrm{kg} \mathrm{BW})$ was administered to rats in Groups II, III and IV after animals were fasted for $24 \mathrm{~h}$. The animals were then sacrificed $4 \mathrm{~h}$ after the administration of indomethacin. The stomach of each animal was removed, incised along the greater curvature and the gastric content was emptied into appropriately labeled sample bottle for determination of gastric volume, pepsin activity, free acidity, and total acidity. The stomach was then washed with normal saline, pinned on a flat surface to observe for lesions/ulcer in the glandular portion.

Table 1: Experimental design and treatment.

\begin{tabular}{|c|c|c|}
\hline Experimental Group & Treatment/Dose/Route & Code \\
\hline Group I & Rats served normal saline & NC \\
\hline Group II & Indomethacin rats left untreated & UC \\
\hline Group III & $\begin{array}{r}\text { Ulcerated rats treated with } \\
\text { cimetidine }(100 \mathrm{mg} / \mathrm{kg} \text { BW/p.o) }\end{array}$ & PC \\
\hline Group IV & $\begin{array}{r}\text { Ulcerated rats treated with PM } \\
(7.1 \mathrm{~mL} / \mathrm{kg} \text { BW/p.o) }\end{array}$ & PM \\
\hline
\end{tabular}

NC: Normal control; UC: Untreated negative Control; PC: Treated Positive Control; PM: Polyherbal Mixture $(n=6)$

\section{Quantification of ulceration}

The ulcerative index and percentage ulcer protection of the different treatments were estimated using the method described by Szabo and Hollander [24]. Based on the intensity of ulceration as observed with a hand lens, the score were given as: $0=$ Normal mucosa; $1=$ Vascular congestion; $2=$ One or two lesions; $3=$ Severe lesions, 4=Very severe lesions, 5=Mucosa full of lesions. The ulcer index was determined using the formula:

Ulcer index $=($ Ulcerated area $/$ total stomach area $) \times 10$

Percentage protection $=(U c-U t) \times 100 / U c$

Where Uc=Ulcer index of control group and Ut=Ulcer index of treated group.

\section{Estimation of free acidity}

The gastric contents were centrifuged at 1000rpm for $10 \mathrm{~min}$. One $\mathrm{mL}$ of the supernatant liquid was pipette out and diluted to $10 \mathrm{~mL}$ with distilled water. The solution was titrated against $0.01 \mathrm{~N} \mathrm{NaOH}$ using Topfer's reagent (dimethyl-amino- 
azo-benzene) as an indicator, to the end point when the solution turned to orange color. The volume of $0.01 \mathrm{~N} \mathrm{NaOH}$ needed was taken as corresponding to the free acidity.

\section{Estimation of total acidity}

Titration was further continued by adding two drops of $1 \%$ solution of phenolphthalein till the solution gained the pink color. The volume of $0.01 \mathrm{~N} \mathrm{NaOH}$ required was noted and was taken as corresponding to the total acidity.

Acidity was expressed as:

Acidity = Volume of $1 \mathrm{~N} \mathrm{NaOH} \mathrm{X} \mathrm{normality} \mathrm{X} 100$ mEq/ L /100 g 0.1

\section{Estimation of pepsin activity}

The assay mixture contained $0.1 \mathrm{~mL}$ gastric juice supernatant (centrifuged at $5000 \times \mathrm{g}$ for $10 \mathrm{~min}$ ) and $1 \mathrm{~mL}$ of bovine albumin $(0.5 \% \mathrm{w} / \mathrm{v}$ in $0.01 \mathrm{~N} \mathrm{HCl}, \mathrm{pH} 2)$ which was incubated for $20 \mathrm{~min}$ at $37{ }^{\circ} \mathrm{C}$. $2 \mathrm{~mL}$ of $10 \%$ trichloroacetic acid was added to stop the hydrolysis. All tubes were heated in boiling water for 5 min to denature the proteins and cooled. The precipitate was removed by centrifugation $(9000 \times \mathrm{g}$ for $10 \mathrm{~min})$, and $1 \mathrm{~mL}$ of the supernatant was mixed with $0.4 \mathrm{~mL}$ of $2.5 \mathrm{~N} \mathrm{NaOH}$ and $0.1 \mathrm{~mL}$ of the Folin-Ciocalteu reagent and the volume was make up to $10 \mathrm{~mL}$ with distilled water. A control set up in which $1 \mathrm{~mL}$ albumin was replaced with $1 \mathrm{~mL}$ of distilled water was run simultaneously. The absorbance was measured at $700 \mathrm{~nm}$. The peptic activity was calculated in terms of micrograms of tyrosine liberated per milliliter of gastric juice according to the method described by Prino et al. [25].

\section{Statistical analysis of data}

The data obtained were statistically analyzed using Graphpad Prism statistical software, version 6.4. Hypothesis testing was by one-way analysis of variance followed by least significant difference test. $\mathrm{P}<0.05$ was considered statistically significant. Results are presented as mean \pm standard deviation $(n=6)$.

\section{Results and Discussion}

Table 2: Effect of PM on pH, free and total acid, and pepsin activity of the gastric juice in indomethacin induced gastric ulcer in Wistar rats.

\begin{tabular}{|c|c|c|c|c|}
\hline Group & $\begin{array}{c}\text { Gastric } \\
\text { Juice }(\mathbf{m l})\end{array}$ & $\begin{array}{c}\text { Free Acidity } \\
\text { (mEq/L) }\end{array}$ & $\begin{array}{c}\text { Total Acidity } \\
\text { (mEq/L) }\end{array}$ & $\begin{array}{c}\text { Pepsin Activity } \\
\text { (mg/mL) }\end{array}$ \\
\hline NC & $7.5 \pm 0.6$ & $35.2 \pm 3.4$ & $49.0 \pm 6.9$ & $189.0 \pm 2.1$ \\
\hline UC & $3.6 \pm 0.4$ & $9.6 \pm 0.6$ & $20.8 \pm 2.5$ & $131.0 \pm 33.6$ \\
\hline PC & $5.8 \pm 0.3^{*}$ & $26.5 \pm 2.2^{*}$ & $37.3 \pm 3.0^{*}$ & $144.5 \pm 6.2^{*}$ \\
\hline PM & $5.1 \pm 0.7^{*}$ & $19.5 \pm 4.1^{*}$ & $23.7 \pm 3.2^{*}$ & $132.7 \pm 10.0$ \\
\hline
\end{tabular}

Values are expressed as mean \pm Standard deviation $(n=5)$. *=statistically significant $(P \leq 0.05)$ compared to UC. NC: Normal Control, UC: Untreated negative Control, PC: Treated Positive Control, PM: Polyherbal Mixture Treatment

Compared to the control animals, single i.p administration of indomethacin at a dose of $40 \mathrm{mg} / \mathrm{kg}$ BW elicited a significant reduction in gastric juice volume, free acidity, total acidity, and pepsin activity in experimental rats. However, oral pre-treatment of the animals with PM showed some significant effects in reducing the negative alterations caused by indomethacin in the animals [Table 2]. PM was able to minimize the indomethacininduced reduction in gastric volume (28.3\%), free acidity (26.1\%), and total acidity (36.7\%). Moreover, the polyherbal mixture showed $25.92 \%$ ulcer protective ability [Table 3]. This mild protection is substantiated by the photomicrographs of the stomach lining of the PM-treated rats (Figure 1).

Table 3: Inhibitory activity of PM on indomethacin induced ulcer in Wistar rats.

\begin{tabular}{|c|c|c|}
\hline Group (Treatment) & $\begin{array}{c}\text { Ulcer (Index } \\
\text { (Mean } \pm \text { SD) }\end{array}$ & Ulcer Inhibition (\%) \\
\hline NC & $0 \pm 0.0$ & - \\
\hline UC & $7.42 \pm 0.28 \mathrm{a}$ & - \\
\hline PC & $4.36 \pm 0.28 \mathrm{c}$ & 41.24 \\
\hline PM & $5.51 \pm 0.28 \mathrm{~b}$ & 25.92 \\
\hline
\end{tabular}

Values with different superscripts are statistically significant $(P \leq 0.05)$ to each other. SD: Standard Deviation; NC: Normal Control, UC: Untreated Negative Control; PC: Treated Positive Control; PM: Polyherbal Mixture
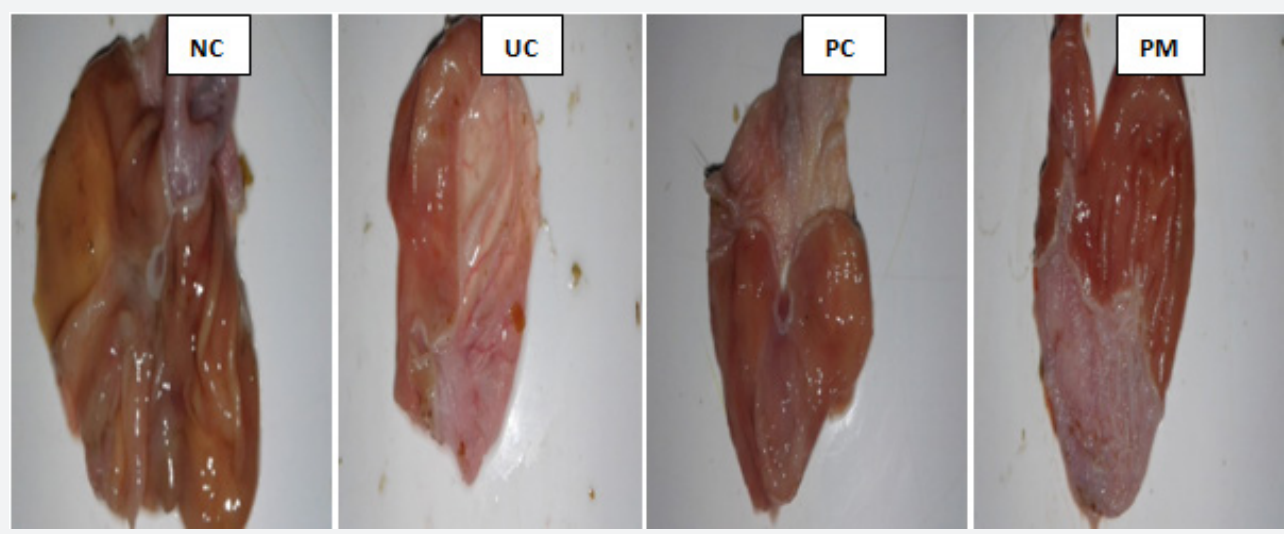

Figure 1: Photomicrographs of the stomach linings of indomethacin-exposed treated and untreated rats.

NC: Normal control, UC: Untreated negative control, PC: Cimetidine-treated and PM: Polyherbal mixture treated. 
As earlier stated the use of herbs and polyherbal formulations to treat various disease conditions is gaining more interest and acceptance for a number of obvious reasons which include low cost, easy availability and assumed fewer side effects compared to synthetic drugs. In addition, the therapeutic efficacy of some individual herbs or combination of herbs is greatly supported by a number of scientific studies. In the present study, the investigated polyherbal formulation (PM) composing of Adenopus breviflorus, Pterocarpus osun and potassium ash showed some anti-ulcerative potential as indicated by its ability to fairly protect the experimental animals against indomethacininduced peptic ulceration. The ability of PM to partly reverse indomethacin-induced ulceration in the experimental animals may be adduced to the ability of some of its phyto-constituents to promote physiological balance between aggressive factors such as pepsin and hydrochloric acid and protective factors like bicarbonate and mucus in the stomach $[10,11]$. The observation made in this study apparently supports the folklore antiulcerative claim on PM and supports previous reports on the use of herbs for management of ulcer $[5,6,11]$. However, the gastro protective effect of PM noted in this investigation is significantly lower than that of Cimetidine, an existing anti-ulcer drug used as a reference drug. Besides, the study outcome does not provide enough therapeutic evidence to recommend or prefer the investigated formulation (PM) as a gastro protective agent relative to existing treatment options.

\section{Conclusion}

Although, the study outcome apparently supports the anti ulcerative claim on $\mathrm{PM}$, the poly herbal mixture is a far less effective antiulcerative agent compared to existing therapeutic options. Moreover, it is necessary to carry out both acute and repeated dose toxicity studies on the 'drug mixture` to ascertain its herbal safety before any recommendations regarding its use as an anti-ulcerative agent is made.

\section{Acknowledgment}

The authors are thankful to the laboratory technologists of the Department of Biochemistry, Lead City University for their support.

\section{References}

1. Aslam MS, Ahmad MS, Mamat AS, Ahmad MZ, Salam F (2016) An update review on polyherbal formulation: A global perspective. Systematic Reviews in Pharmacy 7(1): 35.

2. Dutra RC, Campos MM, Santos AR, Calixto JB (2016) Medicinal plants in Brazil: Pharmacological studies, drug discovery, challenges and perspectives. Pharmacol Res 112: 4-29.

3. Parasuraman S, Thing GS, Dhanaraj SA (2014) Polyherbal formulation: Concept of ayurveda. Pharmacog Rev 8(16): 73-80.

4. Haule EE, Moshi MJ, Nondo RS, Mwangomo DT, Mahunnah RL (2015) A study of antimicrobial activity, acute toxicity and cytoprotective effect of a polyherbal extract in a rat ethanol-HCl gastric ulcer model. BMC Res Notes 5(1): 546.
5. Huang CC, Chen YM, Wang DC, Chiu CC, Lin WT, et al. (2013) Cytoprotective effect of American ginseng in a rat ethanol gastric ulcer model. Molecules 19(1): 316-326.

6. Saxena A, Middha A, Saxena V, Mishra P (2016) Evaluation of antiulcer activity of different extracts of clitoria ternatea leaves on experimental animals. UKJPB 4(3): 60-63.

7. Noto JM, Peek RM (2012) Helicobacter pylori: An overview. Methods Mol Biol 921: 7-10.

8. Stewart B, Khanduri P, McCord C, Ohene-Yeboah M, Uranues S, et al. (2014) Global disease burden of conditions requiring emergency surgery. Br J Surg 101(1): e9-e22.

9. Jesus NZ, Falcão HD, Gomes IF, Leite TJ, Lima GR, et al. (2012) Tannins, peptic ulcers and related mechanisms. Int J Mol Sci 13(3): 3203-3228.

10. Silva MI, de Sousa FC (2011) Gastric ulcer etiology. In Peptic Ulcer Disease. InTech.

11. Ighodaro OM, Adeosun AM, Ojiko BF, Akorede AT, Fuyi-Williams O (2017) Toxicity status and antiulcerative potential of Sansevieria trifasciata leaf extract in Wistar rats. J Intercult Ethnopharmacol 6(2): 234.

12. Konturek PC, Konturek SJ, Brzozowski T (2009) Helicobacter pylori infection in gastric cancerogenesis. J Physiol Pharmacol 60(3): 3-21.

13. Fiorentino M, Ding H, Blanchard TG, Czinn SJ, Sztein MB, et al. (2013) Helicobacter pylori-induced disruption of monolayer permeability and proinflammatory cytokine secretion in polarized human gastric epithelial cells. Infect Immun 81(3): 876-883.

14. Yuan Y, Padol IT, Hunt RH (2006) Peptic ulcer disease today. Nat Clin Pract Gastroenterol Hepatol 3(2): 80-89.

15. Khoder G, AlMenhali AA, AlYassir F, Karam SM (2016) Potential role of probiotics in the management of gastric ulcer. Exp Ther Med 12(1): 3-17.

16. Taketani Y, Kinugasa K, Kitajima R, Nishiumi S, Ashida H, et al. (2014) Protective effects of oral administration of yeast thioredoxin against gastric mucosal injury. Biosci Biotechnol Biochem 78(7): 1221-1230.

17. Hasni SA (2012) Role of Helicobacter pylori infection in autoimmune diseases. Curr Opin Rheumatol 24(4): 429-434.

18. Hoogerwerf WA, Pasricha PJ (2001) Agents used for control of gastric acidity and treatment of peptic ulcers and a gastroesphageal reflex disease. In: Pharmacological basis of Therapeutics. $\left(10^{\text {th }}\right.$ edn $)$, McGrawHill, Newyork, USA, pp. 1005-1019.

19. Srivastava AK, Patil UK, Singhai AS, Kumar MA (2015) Anti-ulcer and antioxidant activity of Nelumbo nucifera gaertn stalks in rats. Int J Pharm Pharm Sci 7(3): 368-373.

20. Al-Sayed E, El-Naga RN (2015) Protective role of ellagitannins from Eucalyptus citriodora against ethanol-induced gastric ulcer in rats: Impact on oxidative stress, inflammation and calcitonin-gene related peptide. Phytomedicine 22(1): 5-15.

21. Bi WP, Man HB, Man MQ (2014) Efficacy and safety of herbal medicines in treating gastric ulcer: A review. World J Gastroenterol 20(45): 17020-17028.

22. Hong S, Lee HA, Lee YS, Kim DW, Oh GW, et al. (2014) Protective effect of halophyte Salsola komarovi Iljin against gastric ulcer Induced by alcohol treatment in rats. Journal of Biomedical Research 15(4): 170175.

23. Weight-control Information Network.

24. Bhattacharya S, Chaudhuri SR, Chattopadhyay S, Bandyopadhyay SK (2007) Healing properties of some Indian medicinal plants against 
indomethacin-induced gastric ulceration of rats. J Clin Biochem Nutr 41(2): 106-114.

25. Szabo S, Hollander D (1989) Pathways of gastrointestinal protection and repair: Mechanisms of action of sucralfate. Am J Med 86(6): 23-31.
26. Prino G, Paglialunga S, Nardi G, Lietti A (1971) Inhibition of experimentally-induced gastric ulcers in the rat by a new sulfated glycopeptide. Eur J Pharmacol 15(1): 119-126.

Your next submission with Juniper Publishers
will reach you the below assets
- Quality Editorial service
- Swift Peer Review
- Reprints availability
- E-prints Service
- Manuscript Podcast for convenient understanding
- Global attainment for your research
- Manuscript accessibility in different formats
( Pdf, E-pub, Full Text, Audio)
- Unceasing customer service
Track the below URL for one-step submission
https://juniperpublishers.com/online-submission.php

